\title{
Indigenes' Use of Development Messages in Newspapers
}

\section{Alex Eloho Umuerri*}

Department of Mass Communication, Benson Idahosa University, Benin, Nigeria

\begin{abstract}
The use of newspapers in the development process in societies has never been in doubt, although it has been quite difficult to determine the papers use in the development process in different situations and societies. Against this backdrop the study investigated the use of development messages in Isoko Mirror, Urhobo Voice, ljaw News, Warri Voice, and Anioma Watch by Isoko, Urhobo, ljaw, Itsekiri, and Anioma indigenes in Delta State, Nigeria. Results from the survey carried out revealed that the dominant gratifications indigenes derived from the newspapers were local awareness and utility (39.9\%), immediacy (33.4\%), and social extension (17.2\%). Majority of respondents $(72.9 \%)$ read the newspapers occasionally, $(18.2 \%)$ often, and $(8.8 \%)$ very often. Furthermore, the dominant satisfactions readers derived from reading the newspapers are for advice (32\%), social utility (24.1), and habit (10.8\%). The development issues that readers found most useful were cultural programme (24.1\%), and political programme $(19.9 \%)$. Indigenes should be encouraged to read local publications with the establishment of newsstands by the community and local groups.
\end{abstract}

\section{Keywords: Development; Communication; information}

\section{Introduction}

The potency of mass media for development purpose is what cited refer to as centralized media, which is predicated on the fact that authorities know more about development priorities and that a good and 'useful' message is capable of being accepted by the people. Therefore the mass media are tools for accelerating information dissemination and development purposes [1-4].

This study considers newspapers, one of such media of mass communication as channel of development information in Delta State, Nigeria. The first newspapers, Iwe Irohin which was established by reverend Henry Townsend and published in Nigeria in 1859, (in Yoruba and English) crusaded the cause of the Egba people of Abeokuta. However, since Townsend stopped publishing Iwe Irohin, Nigeria has produced a number of newspapers in different forms, with communities and groups establishing local newspapers to represent their interests and those of their localities. In five, of the ethnic groups in Delta State, Nigeria - Isoko, Urhobo, Ijaw, Itsekiri, and Anioma there are numerous local newspapers. Among these are: Isoko Mirror, Urhobo Voice, Ijaw News, Warri Voice, and Anioma Watch. These newspapers are owned by individuals within the ethnic groups.

Moemeka [2] has attested to the use of newspapers as a medium with key features of "topicality of contents and reference". Existing research in English language newspapers use for development purposes in Nigeria have mostly focused on national newspapers. There are no known studies of the five ethnic groups' utilization of the development messages contents of the five local newspapers in Delta State Nigeria. It is against this backdrop that the study investigated the use of development messages by readers.

The development communication contents of the local newspapers for investigation are in the areas of agriculture, health, political programme, family planning, housing and environment, economic programme, education, community self-help development, and cultural programme.

\section{The Problem}

Studies on readers' use of development messages have focused on national newspapers published in English in Nigeria at the expense of local newspapers. Very little chance had been given to the possibility that such development messages might have also been reported by the local press.

Newspapers therefore have a role to play in this regard, especially the local press. It is expected that for accelerated development to take place in the localities, issues of politics, agriculture, health, family planning and housing and environment should constitute key development programme. This is in no way to suggest that other development programme not mentioned here are not important in the development process. Readers are therefore expected to give these development items primacy of place in their choice and use of the development messages.

\section{Research Questions}

The study was guided by the following research questions:

1. What gratifications do indigenes derive from the local newspapers; and to what extent do indigenes read the newspapers?

2. What satisfactions do indigenes derive from reading the local newspapers; and which development-oriented information items do the readers find most useful?

\section{Operational Definition of Term}

\section{Indigenes' use of development messages}

The indigenes are the ethnic groups of Isoko, Ijaw, Anioma, Urhobo, and Itsekiri who read and utilize development messages in the following newspapers published by indigenes in their localities: Isoko

*Corresponding author: Alex Eloho Umuerri, Department of Mass Communication Benson Idahosa University, Benin City, Nigeria, Tel: 08055967451; E-mail: alexungng@yahoo.com

Received April 09, 2018; Accepted June 22, 2018; Published June 29, 2018

Citation: Umuerri AE (2018) Indigenes' Use of Development Messages in Newspapers. J Mass Communicat Journalism 8: 375. doi: 10.4172/21657912.1000375

Copyright: (C) 2018 Umuerri AE. This is an open-access article distributed under the terms of the Creative Commons Attribution License, which permits unrestricted use, distribution, and reproduction in any medium, provided the original author and source are credited. 
Mirror, Ijaw News, Anioma Watch, Urhobo Voice, and Warri Voice. Local Newspapers: These are publications in the localities that have a set of news values relevant to a local readership. However, the term local newspapers refer to the institution of local newspapers.

\section{Literature Review}

\section{Perspectives on development and development communication}

An important aspect of this study is to understand the concepts of development and development communication. First, the word 'development' means growth in the life of a person or society. Initially, development was viewed from the position of Gross National Product (GDP). The underlying tenet is that development in a nation is viewed from the perspective of growth in the economy [3]. It has been observed that there was a time when development meant largely an accelerated growth of Gross National Product (GNP), per capita income and structural transformation in the economy. The key to national development was mainly increased rate in savings and capital formation, particularly material capital. The justification for the economic growth view of development is in the fact that at least it gives one greater control over one's environment. This, under normal circumstances, is expected to lead to greater freedom. For instance, economic growth enhances improved techniques and as such yields more abundant and more varied food for less labour. Also, these economic benefits could be far reaching as they can in fact, get to the people in the rural areas, apart from those who can initially benefit.

Another dimension is introduced to the economic factor according to Akinleye [4] in this way; "the classification of the countries of the world into two broad categories - developing countries and industrialized - used to be based almost on the economic criteria alone". In her view the use of Gross National Product (GNP) per capita, low income, middle income and high income economies, to group countries is a clear demonstration that, at that time, the conception of development was purely economic.

However, development is more composite and also humancentered, Oladipo [5] has noted that: development in general is a process of economic and social advancement which enables people to realize their potentials, build self-confidence and lead lives of dignity and fulfilment. It is a process aimed at freeing people from evils of want, ignorance, social injustice and economic exploitation.

While the emphasis above is human centered, Oladipo [5] further postulates that the concept of development should have a paradigm shift which should focus more on the poor and less privileged and disadvantaged in society. Oladipo [5] therefore further conceptualizes Sustainable Human Development (SHD) thus:

Sustainable human development is development that not only generates economic growth but distributes its benefits equitably; that empowers people rather than marginalizing them. It gives priority to the poor, enlarging their choices and opportunities, and provides for their participation in decisions affecting them. It is development that is pro-poor, pro-nature, pro-jobs, pro-women and pro-children.

From the foregoing view, the indices of development are Human Development Index (HDI), Sustainable Human Development (SHD); people-centered development through people's empowerment, popular participation and putting the people first; bottom-up development from the grassroots; environmental accounting and the restructuring of the world economic and financial system along with the UN system and the Breton Woods Institutions [6].
Comparatively, while the first school of thought views development as purely economic, with a strong bias for developing the economy of the state, with income per capita as a very important consideration, the second school of thought is people-centered. In fact, the more recent school of thought has pictured the old paradigm of development as shallow, by claiming that the central focus of development should be man and his well-being. This study is interested in the kind of development that is people-centered.

The reason for this draws from the concepts of development as advanced above, and in addition, development should focus on localities. The justification for this position is that the concepts of development viewed above are from a broad perspective of development as it relates to countries, viz -a-viz the economy and the society at large with a focus on alleviating the suffering of the people. While these concepts remain relevant and will continue to remain relevant, the argument has been whether the concept should continue to cover these broad perspectives alone. It, therefore, seems logical to look at development from a position that is relevant to this study. From this perspective, development is seen as a change in all spheres of human endeavors and the economy of a state and in particular Sustainable Infrastructural and Human Developments (SIHD) which must impact positively on localities. The focal point of view therefore is the localities, which bear great responsibilities of development. One needs not overemphasize this point because the state and national governments have always been involved in developments.

Another important aspect of the study is to understand the concept of development communication. It refers to the channel of communication through which development information is disseminated, for instance newspapers. According to Udoakah [7] cited by Sage Laninhun [8], development communication is about how communication can be used for organized development. It is an attempt to influence the public to accept new ideas, to win citizens over to new ways of doing things. Development communication is therefore corrective, integrative and revolutionary in nature. It is result-oriented Salawu [9], citied by Sage Laninhun [8], also note that development communication "stresses access to the media of communication, participation in communication activities and the relevance of content to the socio-cultural context".

Moemeka [2] defines development communication as the application of the process of communication to the development process. In other words, development communication is the use of the principles and practices of exchange of ideas to fulfill development objectives.

From the foregoing reviews, development communication implies the use of the media to highlight and emphasize development issues with a people oriented bias. This therefore, clearly suggests that the newspaper can indeed be used as a vehicle for development communication in localities and in the rural setting to spread knowledge and information in order to contribute to changing people's behavior and creating development.

The recourse to advancing this concept is that the localities have a crucial role to play in development. Scholarly evidence abound that laments the failure of the national press to be a prime mover of development $[10,11]$.

\section{Empirical Literature Review}

We provide empirical literature that is related to the study. On the global state of newspaper, Kung et al. [12] have said that there has 
been a gradual worldwide decline in newspaper reading. This above position is supported by Elvestad and Blekesaune [13] in their study of percentage of non-readers in the adult population of some European countries in 2004. The countries used for the study are Norway, Switzerland, Estonia, Germany, United Kingdom, Poland, France, Spain and Greece.

Ogbemi [14] investigated newspaper readership in Port Harcourt to find out among other things which newspaper is read most by respondents of Port Harcourt, capital of Rivers State, Nigeria, and whether sex, educational level, and income affects readership in the city. The survey research method and the uses and Gratifications Theory were applied. Results revealed that majority respondents $60.5 \%$ read newspapers daily. Also, results showed that respondents with higher income than those with lower income will read newspapers. Also, men will read newspapers more than women. Umuerri [15] investigated the readership of and use of development messages of two selected Isoko newspapers in Delta State, Nigeria. The local newspapers are Isoko Mirror and Isoko Times Extra. The survey method was employed and results showed that there was a high level of awareness of Isoko newspapers with 172 or $71 \%$ of the respondents answering in the affirmative. Also, the highest number of development items respondents claimed they found in the selected newspapers were democracy messages, 57 or $23 \%$. The study was conducted in the two Isoko council areas of Isoko South with headquarters in Oleh and Isoko North with headquarters in Ozoro.

\section{Theoretical Framework}

This study was guided by the Uses and Gratifications Theory. Little John (1992) has observed that the approach focuses on the consumer, the audience member rather than the message. This approach imagines the audience member to be a discriminatory user of the media. It views the members of the audience as actively utilizing media contents, rather than being passively acted upon by the media. Folarin [16] provides further insight to this theory when he notes that the question is on who uses which contents from which media under which conditions and for what reasons.

The scenario, according to Folarin, is: An individual has some needs related to communication; He/She selects the media that appear likely to satisfy those needs; He/She selectively consumes the content; an effect may or may not occur [17].

The theory is captured by Katz et al. [18] in this way: “... it is the program that asks the question, not "what do the media do to people? But "what do people do with the media? The theory is based on the following assumptions as stated by Katz et al. [18]:

1. The audience is assumed to be an active user of mass media.

2. Each audience member must discern which medium will best gratify his or her needs for a given use.

3. Media outlets compete with other sources of gratification and media cannot satisfy all human needs.

4. Empirical data assessment can help determine the goals of mass media consumers since users are self-aware enough to accurately describe their motives.

5. Judgments about the cultural relevance of mass media must be withheld in order to avoid speculation on popular culture.

According to Katz et al. [18] the framework for the uses and gratifications theory is as follows:
1. The audience is conceived of as active, an important part of mass media use is assumed to be goal directed.

2. In the mass communication process much initiative in linking need gratification and media choice lies with the audience member. This places a strong limitation on theorizing about any form of straight line effect of media content on attitudes and behavior.

3. The media compete with other sources of need satisfaction

4. Many of the mass media use can be derived from data supplied by individual audience members themselves.

Arising from this theory, the readers identified in this study are those of Isoko, Urhobo, Ijaw, Itsekiri and Anioma ethnic groups who are crucial to our discussion. The concept of uses and gratifications implies the use of the local newspapers i.e., Isoko Mirror, Urhobo Voice, Ijaw News, Warri Voice and Anioma Watch. The identified audiences above are expected to use the local newspapers for personal benefits by reading the contents in the areas of agriculture, health, education, cultural, community self-help development, housing and environment, family planning, political, and economic programmes, and also, by seeking appropriate advice and taking action based on the information provided in the newspapers.

Therefore, the uses and gratifications theory places emphasis on the foregoing development areas and how the audiences use these needs. The audiences are those of Isoko, Urhobo, Ijaw, Itsekiri and Anioma and we looked at how the demographics of sex, age, education level, and income influence their use of the newspapers. These audiences from the theory can be applied to the local media. The local newspapers are Isoko Mirror, Urhobo Voice, Ijaw News, Warri Voice and Anioma Watch. Therefore, the audiences of Isoko, Urhobo, Ijaw, Itsekiri and Anioma indigenes present a good picture/example for demographic study.

\section{Theoretical Roots of the Research Questions}

\section{Research question one}

What Gratifications do indigenes derive from the local newspapers; and to what extent do indigenes read the local newspapers?

This research question originated from assumption one of Bulmer and Katz [19] uses and Gratifications Theory thus: "The audience is assumed to be an active user of mass media".

\section{Research question two}

What satisfactions do indigenes derive from reading the local newspapers; and which development oriented information items do the readers find most useful?

The root of this question is from assumption two (2) of Bulmer and Katz ([19] uses and Gratifications Theory which states that; "Each audience member must discern which medium will best gratify his or her needs for a given use".

\section{Methodology}

Survey method was adopted in conducting the research and was used to study the population of Isoko, Urhobo, Ijaw, Itsekiri and Anioma in Delta State, with a focus on their use of the following newspapers: Isoko Mirror, Urhobo Voice, Ijaw News, Warri Voice and Anioma Watch for purposes of development messages. 
The population of the five ethnic groups of Isoko, Urhobo, Ijaw, Itsekiri, and Anioma make up the total population of Delta state which is 4,112,445 of which 2,069,309 are males and 2,043,136 females [20]. From the tables, the literate population of Delta State is $2,708,088$. It is assumed that the population represented the reading population. Gbadegesin [21] noted that, "a population is the set representing all measurements of interests to the research".

The convenience sampling technique was used to draw sample from the population Convenience sampling, according to the authors $[22,23]$, is a non-probability sampling strategy that uses the most easily accessible people ( or objects ) to participate in a study.

Five sets of the same questionnaire were administered with the help of trained research assistants in the five locations of Oleh, Asaba, Patani, Effurun and Warri. A total of 130 copies of the questionnaire were each administered to respondents in the five locations. In Oleh, copies of the questionnaire were distributed to the following quarters of Eviewoh, Okporoh and Uzorkpah. Each of the quarters had 43 copies of the questionnaire except Uzorkpah which had 44, totaling 130, out of which 128 of the questionnaire were returned. In Effurun, copies of the questionnaire were distributed to the following quarters of Enerhen and Ebrumede with each having 65 and all were returned by respondents. In Patani, copies of the questionnaire were distributed to two quarters of Ekise and Abare, each quarter had 65, 126 copies of the questionnaire were returned. In Warri, 65 copies of the questionnaire were distributed to the two quarters of Ajamimogha, and Okere, while 129 copies were returned. In Asaba, 65 copies each of the questionnaire were distributed in Ogbogonogo, and Okpanam, while 127 were retrieved from respondents.

The copies of the questionnaire were given to students, teachers, civil servants, politicians, and businessmen, as the areas surveyed were made up of these different groups of respondents. Because the different groups of respondents had varying demographic variables of age, gender, education, and economic levels, convenience sampling was thought necessary. A sample of 650 respondents was chosen out of which 640 copies of the questionnaire were returned by respondents. Since convenience sampling was thought necessary to include all the demographic variables of age, gender, income, and level of education, a uniform sample size of 130 respondents was further chosen to represent each of the five localities of Asaba, Effurun, Warri, Patani, and Oleh. The copies of the questionnaire were distributed by trained researchers to offices, homes, schools and business premises or centers. Five research assistants, who were trained, distributed and retrieved the copies of the questionnaire in the following areas: Two research assistants in Asaba; One each in Oleh; Warri; and Patani. Copies of the questionnaire were self-administered in Effurun. Frequency counts and simple percentages distribution were used for data analysis and presentation.

\section{Results and Discussion}

\section{Research question one}

What gratifications do indigenes derive from the local newspapers; and to what extent do indigenes read the local newspapers?

This research question sought to determine the gratifications indigenes derived from the local newspapers, and the extent to which indigenes read the local newspapers. It examined whether the local newspapers play a leading role in shaping perception as well as reality in the localities. To answer this question, the starting point was to determine the gratification of indigenes when they read the monthly and weekly local newspapers. The information on this is provided in Table 1 below.

Table 1 that the gratifications of indigenes when they read the monthly and weekly newspapers were for local awareness and utility, immediacy, and social extension in that order. However, the monthly and weekly newspapers presented different gratifications for readers.

The monthly newspapers presented 119 (58.6\%) items of gratifications by indigenes in the localities of Oleh, Patani and Warri, as against 84 (41.3\%) of gratifications in Effurun and Asaba by the weekly newspapers.

On the aggregate, one can safely infer that readers' gratifications were to be informed for local issues and news events in their immediate environment, as this accounted for the total indigenes' gratifications as follows: "local awareness and utility" (81), "immediacy" (68), and "social extension" (35).

It was also necessary to ascertain their frequency of reading the local newspapers. The data are presented in Table 2 below.

The Table 2 above shows that $72.9 \%$ of the respondents read the newspapers occasionally. Other frequencies with which respondents read the newspapers were "Often" (18.2\%) and "Very Often" $(8.8 \%)$. This result is an indication that readers of local newspapers in Delta State were few and a reason for this is not far to seek, as illiteracy is still a problem in Nigeria. This has led to poor reading habits. For instance, Moemeka [2] cites the Europa Year Book (Vol. 1: 1992) as having given the following statistics on this:

Cameroon with a population of 112 million (1989) has 29 daily newspapers hampered by high production costs, limited readership...

\begin{tabular}{|c|c|c|c|c|c|c|c|c|c|c|}
\hline \multicolumn{5}{|c|}{ Monthly Newspapers } & \multicolumn{6}{|c|}{ Weekly Newspapers } \\
\hline $\mathbf{S} / \mathbf{N}$ & Gratifications & - & $\begin{array}{l}\text { Oleh/IM } \\
\text { No. } \%\end{array}$ & $\begin{array}{l}\text { Patani//N } \\
\text { No. } \%\end{array}$ & $\begin{array}{l}\text { Warri/WV } \\
\text { No. } \%\end{array}$ & No. of Monthly & $\begin{array}{c}\text { Effurun/UV } \\
\text { No. } \%\end{array}$ & $\begin{array}{l}\text { Asaba } \\
\text { No. } \%\end{array}$ & $\begin{array}{l}\text { No. of } \\
\text { Weekly }\end{array}$ & Total \\
\hline 1 & Immediacy & $\begin{array}{c}\text { Count } \\
\% \text { within immediacy }\end{array}$ & $\begin{array}{c}16 \\
23.5 \%\end{array}$ & $\begin{array}{c}12 \\
17.6 \%\end{array}$ & $\begin{array}{c}11 \\
16.16\end{array}$ & 39 & $\begin{array}{c}18 \\
26.4 \%\end{array}$ & $\begin{array}{c}11 \\
16.1 \%\end{array}$ & 29 & $\begin{array}{l}68(33.4) \\
100 \%\end{array}$ \\
\hline 2 & $\begin{array}{l}\text { Local Awareness } \\
\text { and Utility }\end{array}$ & $\begin{array}{c}\text { Count } \\
\% \text { within Local Awareness } \\
\text { and Utility }\end{array}$ & $\begin{array}{c}20 \\
24.6 \%\end{array}$ & $\begin{array}{c}16 \\
19.7 \%\end{array}$ & $\begin{array}{c}14 \\
17.2 \%\end{array}$ & 50 & $\begin{array}{c}22 \\
27.1 \%\end{array}$ & $\begin{array}{c}09 \\
11.1 \%\end{array}$ & 31 & $\begin{array}{c}81(39.9) \\
100 \%\end{array}$ \\
\hline 3 & Entertainment & $\begin{array}{c}\text { Count } \\
\% \text { within entertainment }\end{array}$ & $\begin{array}{c}05 \\
26.3 \%\end{array}$ & $\begin{array}{c}03 \\
15.7 \%\end{array}$ & $\begin{array}{c}02 \\
10.5 \%\end{array}$ & 10 & $\begin{array}{c}06 \\
31.5 \%\end{array}$ & $\begin{array}{c}03 \\
15.7 \%\end{array}$ & 09 & $\begin{array}{c}19(9.3) \\
100 \%\end{array}$ \\
\hline 4 & Social Extension & $\begin{array}{c}\text { Count } \\
\% \text { within Social Extension }\end{array}$ & $\begin{array}{c}08 \\
22.8 \%\end{array}$ & $\begin{array}{c}05 \\
14.2 \%\end{array}$ & $\begin{array}{c}07 \\
20 . \%\end{array}$ & 20 & $\begin{array}{c}10 \\
28.5 \%\end{array}$ & $\begin{array}{c}05 \\
14.2 \%\end{array}$ & 15 & $\begin{array}{c}35(17.2) \\
100 \%\end{array}$ \\
\hline & Total & $\begin{array}{c}\text { Count } \\
\% \text { within gratifications }\end{array}$ & $\begin{array}{c}49 \\
24.7\end{array}$ & $\begin{array}{c}36 \\
17.7\end{array}$ & $\begin{array}{c}34 \\
16.7\end{array}$ & $\begin{array}{l}119 \\
58.6\end{array}$ & $\begin{array}{c}56 \\
27.5\end{array}$ & $\begin{array}{c}28 \\
13.7\end{array}$ & $\begin{array}{c}84 \\
41.3\end{array}$ & $\begin{array}{c}203 \\
100 \%\end{array}$ \\
\hline
\end{tabular}

IM: Isoko Mirror; IN: Ijaw News; WV: Warri Voice; UV: Urhobo Voice; AW: Anioma Watch.

Table 1: Gratifications Indigenes derive from the Monthly and Weekly Newspapers: Total Indigenes Gratification Cross Tabulations 
Citation: Umuerri AE (2018) Indigenes' Use of Development Messages in Newspapers. J Mass Communicat Journalism 8: 375. doi: 10.4172/21657912.1000375

Page 5 of 7

\begin{tabular}{|c|c|c|c|c|c|c|}
\hline $\mathbf{S} / \mathbf{N}$ & Locations/ Newspapers & $\begin{array}{l}\text { Very Often } \\
\text { No. } \%\end{array}$ & $\begin{array}{l}\text { Often } \\
\text { No. } \%\end{array}$ & $\begin{array}{l}\text { Occasionally } \\
\text { No. } \%\end{array}$ & $\begin{array}{c}\text { Number of Respondents } \\
\text { No. } \%\end{array}$ & Total \\
\hline & Monthly & & & & & \\
\hline 1 & Oleh/IM & $\begin{array}{c}5(10.2) \\
(27.7)\end{array}$ & $\begin{array}{c}8(16.3) \\
(21.6)\end{array}$ & $\begin{array}{c}36(73.4) \\
(24.3)\end{array}$ & $49(24.1)$ & $100 \%$ \\
\hline 2 & Patani/IN & $\begin{array}{r}3(8.3) \\
(16.6)\end{array}$ & $\begin{array}{c}6(16.6) \\
(10.8)\end{array}$ & $\begin{array}{c}27(75 .) \\
(18.2)\end{array}$ & $36(17.7)$ & $100 \%$ \\
\hline \multirow[t]{2}{*}{3} & Warri/WV & $\begin{aligned} 3(8.8) \\
(16.6)\end{aligned}$ & $\begin{array}{c}4(11.7) \\
(10.8)\end{array}$ & $\begin{array}{l}27(79.4) \\
\quad(46.5)\end{array}$ & $34(16.7)$ & $100 \%$ \\
\hline & Sub-Total Weekly & 11 & 18 & 90 & 119 & \\
\hline 4 & Effurun/UV & $\begin{array}{c}7(12.5) \\
(38.8)\end{array}$ & $\begin{array}{c}11(19.6) \\
(27.7)\end{array}$ & $\begin{array}{l}38(67.8) \\
(79.1)\end{array}$ & $56(27.5)$ & $100 \%$ \\
\hline \multirow[t]{3}{*}{5} & Asaba/AW & - & $\begin{array}{c}8(28.5) \\
(21.6)\end{array}$ & $\begin{array}{l}20(71.4) \\
\quad(13.5)\end{array}$ & $28(13.7)$ & $100 \%$ \\
\hline & Sub Total & 7 & 19 & 58 & 84 & \\
\hline & Total & $18(8.8)$ & $37(18.2)$ & $48(72.9)$ & 203 & $100 \%$ \\
\hline
\end{tabular}

IM: Isoko Mirror; IN: Ijaw News; WV: Warri Voice; UV: Urhobo Voice; AW: Anioma Watch.

Table 2: Frequency of Reading the Local Newspapers.

\begin{tabular}{|c|c|c|c|c|c|c|c|c|c|c|}
\hline S/N & Satisfactions & - & $\begin{array}{l}\text { Oleh } / I M \\
\text { No. } \%\end{array}$ & $\begin{array}{l}\text { Patani/IN } \\
\text { No. } \%\end{array}$ & $\begin{array}{c}\text { Warri/ } W V \\
\text { No. } \%\end{array}$ & $\begin{array}{l}\text { No. \% } \\
\text { Monthly }\end{array}$ & $\begin{array}{c}\text { Effurun/ } \\
\text { UV } \\
\text { No. } \%\end{array}$ & $\begin{array}{c}\text { Asaba/ } \\
\text { AW } \\
\text { No. } \%\end{array}$ & $\begin{array}{l}\text { No. } \% \\
\text { Weekly }\end{array}$ & Total \\
\hline 1 & Habit & $\begin{array}{c}\text { Count } \\
\% \text { within Habit }\end{array}$ & $\begin{array}{c}06 \\
27.2 \%\end{array}$ & $\begin{array}{c}03 \\
13.6 \%\end{array}$ & $\begin{array}{c}03 \\
13.6 \%\end{array}$ & 12 & $\begin{array}{c}08 \\
36 \%\end{array}$ & $\begin{array}{c}02 \\
9.0 \%\end{array}$ & 10 & $\begin{array}{c}22(10.8) \\
100 \%\end{array}$ \\
\hline 2 & Convenience & $\begin{array}{c}\text { Count } \\
\% \text { within Convenience }\end{array}$ & $\begin{array}{c}03 \\
20 . \%\end{array}$ & $\begin{array}{c}02 \\
13.3 \%\end{array}$ & $\begin{array}{c}04 \\
26.6\end{array}$ & 09 & $\begin{array}{c}04 \\
26.6 \%\end{array}$ & $\begin{array}{c}02 \\
13.3 \%\end{array}$ & 6 & $\begin{array}{c}15(7.3) \\
100 \%\end{array}$ \\
\hline 3 & Social Utility & $\begin{array}{c}\text { Count } \\
\% \text { within Social Utility }\end{array}$ & $\begin{array}{c}12 \\
24.4 \%\end{array}$ & $\begin{array}{c}09 \\
18.3 \%\end{array}$ & $\begin{array}{c}10 \\
20.4 \%\end{array}$ & 31 & $\begin{array}{c}10 \\
20.4 \%\end{array}$ & $\begin{array}{c}08 \\
16.3 \%\end{array}$ & 18 & $\begin{array}{c}49(24.1) \\
100 \%\end{array}$ \\
\hline 4 & $\begin{array}{l}\text { Escape From } \\
\text { Problems }\end{array}$ & $\begin{array}{c}\text { Count } \\
\% \text { within Escape from problems }\end{array}$ & $\begin{array}{c}02 \\
14.2 \%\end{array}$ & $\begin{array}{c}04 \\
28.5 \%\end{array}$ & $\begin{array}{c}02 \\
14.2 \%\end{array}$ & 08 & $\begin{array}{c}03 \\
21.4 \%\end{array}$ & $\begin{array}{c}03 \\
21.4 \%\end{array}$ & 6 & $\begin{array}{l}1(6.8) \\
100 \%\end{array}$ \\
\hline 5 & Advice & $\begin{array}{c}\text { Count } \\
\% \text { within Advice }\end{array}$ & $\begin{array}{c}17 \\
26.1 \%\end{array}$ & $\begin{array}{c}12 \\
18.4 \%\end{array}$ & $\begin{array}{c}11 \\
16.9 \%\end{array}$ & 40 & $\begin{array}{c}16 \\
34.6 \%\end{array}$ & $\begin{array}{c}09 \\
13.8 \%\end{array}$ & 25 & $\begin{array}{c}65(32 .) \\
100 \%\end{array}$ \\
\hline 6 & Entertainment & $\begin{array}{c}\text { Count } \\
\% \text { within Entertainment }\end{array}$ & $\begin{array}{c}05 \\
27.7 \%\end{array}$ & $\begin{array}{c}02 \\
11.1 \%\end{array}$ & $\begin{array}{c}02 \\
11.1 \%\end{array}$ & 09 & $\begin{array}{c}06 \\
33.3 \%\end{array}$ & $\begin{array}{c}03 \\
16.6 \%\end{array}$ & 9 & $\begin{array}{c}18(8.8) \\
100 \%\end{array}$ \\
\hline 7 & $\begin{array}{l}\text { Escape from } \\
\text { boredom }\end{array}$ & $\begin{array}{c}\text { Count } \\
\% \text { within Escape from boredom }\end{array}$ & $\begin{array}{c}04 \\
20{ }^{\wedge}\end{array}$ & $\begin{array}{c}04 \\
20 . \%\end{array}$ & $\begin{array}{c}02 \\
10 . \%\end{array}$ & 10 & $\begin{array}{c}09 \\
45 . \%\end{array}$ & $\begin{array}{c}01 \\
0.5 \%\end{array}$ & 10 & $\begin{array}{c}20(9.8) \\
100 \%\end{array}$ \\
\hline & Total & $\begin{array}{c}\text { Count } \\
\% \text { within Satisfactions }\end{array}$ & $\begin{array}{c}49 \\
24.1\end{array}$ & $\begin{array}{c}36 \\
17.7\end{array}$ & $\begin{array}{c}34 \\
16.7\end{array}$ & $\begin{array}{r}119 \\
58.6\end{array}$ & $\begin{array}{c}56 \\
27.5\end{array}$ & $\begin{array}{c}28 \\
13.7\end{array}$ & $\begin{array}{c}84 \\
41.3\end{array}$ & $203100 \%$ \\
\hline
\end{tabular}

IM: Isoko Mirror; IN: Ijaw News; WV: Warri Voice; UV: Urhobo Voice; AW: Anioma Watch.

Table 3: Comparison of Satisfactions of Indigenes when they read the Monthly and Weekly Local Newspapers. Total Indigenes Satisfactions Cross Tabulations.

Egypt with a population of 53 million (1990) has 17 daily newspapers hampered by high illiteracy rate.

That information is also a reflection of what obtains in most African countries and Nigeria; in particular. Therefore, only a few respondents read the papers regularly. This is not consistent with the finding of Salawu [9] that a majority of respondents 227 or $63.1 \%$ read Yoruba newspapers. The author had investigated the readership of Yoruba newspapers for development messages.

\section{Research question two}

What satisfactions do indigenes derive from reading the local newspapers; and which development oriented information items do the readers find most useful?

This research question sought to investigate the satisfactions derived by indigenes when they read the newspapers; and the development information that readers find most useful. There was therefore need to carry out a comparison between satisfactions derived by indigenes when they read the monthly and weekly newspapers. The information on this is provided in Table 3 .

The Table 3 shows that there were more indigenes that derived satisfactions reading monthly newspapers than they did reading weekly newspapers. This information can be gleaned from the table. Also, "Advice" (65), and "social utility" (49) were the major or leading satisfactions derived by indigenes when they read the local newspapers. When separated differently, however, the local newspapers presented different levels of satisfactions to readers. Urhobo Voice, a weekly, was the leading local newspapers in this direction with (56) items, followed by Isoko Mirror (49), Ijaw News (36), Warri Voice (34) and Anioma Watch (28). The inference that can be drawn is that the readers' preferred to use to use the local newspapers to solve specific needs of development by relying on the newspapers for advice and using for social utility.

Furthermore, there was need to investigate the development messages that readers found most useful in the monthly and weekly local newspapers. The information on this can be gleaned from Table 4 .

Table 4 presents data on development messages that respondents/ readers found most useful. The summary of the data shows that respondents were of the opinion that they preferred "cultural programme" $(24.1 \%)$ to other development messages reported in the local newspapers [24].

\section{Conclusion}

The result has shown that or emphasized the point that culture is a way of life of the people which they always want to cling to. 
Citation: Umuerri AE (2018) Indigenes' Use of Development Messages in Newspapers. J Mass Communicat Journalism 8: 375. doi: 10.4172/21657912.1000375

Page 6 of 7

\begin{tabular}{|c|c|c|c|c|c|c|c|c|c|c|}
\hline \multicolumn{5}{|c|}{ Monthly } & \multirow[b]{2}{*}{$\begin{array}{c}\text { Warri/WV } \\
\text { No. } \%\end{array}$} & \multirow[b]{2}{*}{$\begin{array}{l}\text { No. of } \\
\text { Items in the } \\
\text { Monthly }\end{array}$} & \multicolumn{4}{|c|}{ Weekly } \\
\hline$S / N$ & Development & & $\begin{array}{l}\text { Oleh/IM } \\
\text { No. } \%\end{array}$ & $\begin{array}{l}\text { Patani/IN } \\
\text { No. } \%\end{array}$ & & & $\begin{array}{c}\text { Effurun/UV } \\
\text { No. } \%\end{array}$ & $\begin{array}{l}\text { Asaba/AW } \\
\text { No. } \%\end{array}$ & $\begin{array}{l}\text { No. of } \\
\text { Items in the } \\
\text { Weekly }\end{array}$ & $\begin{array}{l}\text { Total } \\
\text { No. } \%\end{array}$ \\
\hline 1 & Agriculture & Count $\%$ within Agriculture & $\begin{array}{c}1(20 .) \\
(2 .)\end{array}$ & $\begin{array}{l}1(20 .) \\
(2.9)\end{array}$ & $\begin{array}{l}1(20 .) \\
(2.9)\end{array}$ & 3 & - & $\begin{array}{c}2(40 .) \\
(7.1)\end{array}$ & 2 & $5(2.4)$ \\
\hline 2 & Health & $\begin{array}{c}\text { Count } \\
\% \text { within Health }\end{array}$ & $\begin{array}{c}2(11.1) \\
(4.1)\end{array}$ & $\begin{array}{c}1(5.5) \\
(2.7)\end{array}$ & $\begin{array}{c}3(16.6) \\
(8.8)\end{array}$ & 6 & $\begin{array}{l}11(61.1) \\
(19.6)\end{array}$ & $\begin{array}{c}1(5.5) \\
(3.5)\end{array}$ & 12 & $18(8.8)$ \\
\hline 3 & $\begin{array}{c}\text { Political } \\
\text { Programmes }\end{array}$ & $\begin{array}{c}\text { Count } \\
\% \text { within Political } \\
\text { Programmes }\end{array}$ & $\begin{array}{c}6(16.6) \\
(12.2)\end{array}$ & $\begin{array}{c}11(30.5) \\
(30.5)\end{array}$ & $\begin{array}{c}6(16.6) \\
(7.6)\end{array}$ & 23 & $\begin{array}{c}6(16.6) \\
(10.7)\end{array}$ & $\begin{array}{c}7(19.4) \\
\quad(25 .)\end{array}$ & 13 & $36(17.7)$ \\
\hline 4 & Family Planning & $\begin{array}{c}\text { Count } \\
\% \text { within Family Planning }\end{array}$ & $\begin{array}{l}1(50 .) \\
(2 .)\end{array}$ & $\begin{array}{c}1(50 .) \\
(2.7)\end{array}$ & - & 2 & - & - & & $2(0.9)$ \\
\hline 5 & $\begin{array}{l}\text { Housing and } \\
\text { Environment }\end{array}$ & $\begin{array}{c}\text { Count } \\
\% \text { within Housing and } \\
\text { Environment }\end{array}$ & $\begin{array}{c}1(16.6) \\
(2 .)\end{array}$ & - & - & 1 & $\begin{array}{c}4(66.6) \\
(7.1)\end{array}$ & $\begin{array}{c}1(16.6) \\
\quad(3.5)\end{array}$ & 5 & $6(2.9)$ \\
\hline 6 & $\begin{array}{c}\text { Economic } \\
\text { Programmes }\end{array}$ & $\begin{array}{c}\text { Count } \\
\text { \% within Economic } \\
\text { Programmes }\end{array}$ & $\begin{array}{c}9(34.6) \\
(18.3)\end{array}$ & $\begin{array}{c}4(15.3) \\
(11.1)\end{array}$ & - & 13 & $\begin{array}{c}8(30.7) \\
(14.2)\end{array}$ & $\begin{array}{c}5(19.2) \\
\quad(7.8)\end{array}$ & 13 & $26(12.8)$ \\
\hline 7 & Education & $\begin{array}{c}\text { Count } \\
\% \text { within Education }\end{array}$ & $\begin{array}{c}10(28.4) \\
(20.4)\end{array}$ & $\begin{array}{c}6(17.1) \\
(16.6)\end{array}$ & $\begin{array}{c}4(11.4) \\
(11.7)\end{array}$ & 20 & $\begin{array}{c}12(34.4) \\
(21.4)\end{array}$ & $\begin{array}{r}3(8.5) \\
(10.7)\end{array}$ & 15 & $35(17.2)$ \\
\hline 8 & $\begin{array}{l}\text { Community Self- } \\
\text { Help Development }\end{array}$ & $\begin{array}{c}\text { Count } \\
\% \text { within Community Self- } \\
\text { Help Development }\end{array}$ & $\begin{array}{c}8(30.7) \\
(16.3)\end{array}$ & $\begin{array}{c}4(15.3) \\
(11.1)\end{array}$ & $\begin{array}{c}7(26.9) \\
(20.5)\end{array}$ & 19 & $\begin{array}{c}5(19.2) \\
(8.9)\end{array}$ & $\begin{array}{c}2(7.6) \\
(7.1)\end{array}$ & 7 & $26(12.8)$ \\
\hline 9 & $\begin{array}{c}\text { Cultural } \\
\text { Programmes }\end{array}$ & $\begin{array}{c}\text { Count } \\
\% \text { within Cultural } \\
\text { Programmes }\end{array}$ & $\begin{array}{c}11(22.4) \\
(22.4)\end{array}$ & $\begin{array}{c}8(16.3) \\
(22.2)\end{array}$ & $\begin{array}{c}13(26.5) \\
(38.2)\end{array}$ & 32 & $\begin{array}{c}10(20.4) \\
(17.8)\end{array}$ & $\begin{array}{c}7(14.2) \\
\quad(25 .)\end{array}$ & 17 & $49(24.1)$ \\
\hline & Total & $\begin{array}{c}\text { Count } \\
\% \text { within development } \\
\text { items }\end{array}$ & $\begin{array}{c}49 \\
24.1\end{array}$ & $\begin{array}{c}36 \\
17.7\end{array}$ & $\begin{array}{c}34 \\
16.7\end{array}$ & $\begin{array}{c}119 \\
58.6\end{array}$ & $\begin{array}{c}56 \\
27.5\end{array}$ & $\begin{array}{c}28 \\
13.7\end{array}$ & $\begin{array}{c}84 \\
41.3\end{array}$ & $203(100)$ \\
\hline
\end{tabular}

Table 4: Development Messages Respondents Find Most Useful in the Monthly and Weekly Local Newspapers.

Another high ranking subcategory of development messages which readers find most useful in the local newspapers are political programme. The attraction to political programme by indigenes is not surprising, since the love to have power derives from political office. It is generally believed that with power at their disposal, people can overcome other challenges of development. Corroborated this in his study on sources of political information in rural Nigerian community.

However, the respondents' rating of family planning subcategory $(0.9 \%)$ is an indication that issues of family planning are not taken seriously. This result is not consistent with study and rating of family planning programme through the use of broadcast media. The researcher had investigated the use of broadcast media in family planning matters in Ebele Community in Igueben Local Government Area of Edo state.

\section{Recommendations}

Based on the findings, the study recommends as follows:

1. Indigenes should be encouraged to read local publications. This can be done with the establishment of newsstands by the community, local groups or non-governmental organizations.

2. While it is laudable that indigenes continue to cling to age-old traditions of their cultural beliefs, it is necessary for them to accept certain alterations that may be made on some aspects of these traditions, which may be barbaric and or which may have become inimical to local aspirations. Some of these new cultural aspirations should be issues for discussion and subsequent publications in the newspaper.

\section{References}

1. Gunter J, Theroux J (1977) Open Broadcast Education Radio: Three Paradigms. In Rogers (ed.) Radio for Education and Development Case
Studies. Washington, DC: World Bank.

2. Moemeka AA (2008) Development Communication in Action. Maryland: University Press of America.

3. McQuail D (2010) Mass Communication Theory, (6 $6^{\text {th }}$ edn.)_, London: Sage Publication.

4. Akinleye L (2003) Indigenious knowledge system: Communication and Sustainable Development in Soola EO (ed.) Communicating for Development Purposes. Ibadan: Kraft Books 61-73.

5. Oladipo EO (1996) The Theory, Concept and Practice of Sustainable Human Development. Lagos: UNDP.

6. Onimade B (1995) Overview of Nigeria's Development and Planning Experience. Paper presented at a Workshop on Agenda for Sustainable Human Development in Nigeria, Sponsored by United Nations Development System, Ibadan

7. Udoakah N (1998) Nigeria's Early Communication Media: How Relevant in Information Society and Democracy Journal of Humanities 5: 135-143.

8. Sage Laninhun A (2003) Communicating for Development Purposes: A Gender Perspective. In: Soola EO editors. Communicating For Development Purposes. Ibadan: Kraft Books Chapter 4: 72-86.

9. Salawu AS (2004) An Evaluation of The Development Communication Contents of Yoruba Newspapers. Communication and Language Arts, Arts, University Of Ibadan.

10. Abayode B (1987) The provision of Information for Rural Development, Ibadan: Foundation Publications.

11. Adesanoye FA (1990) Mass Communication, Mass Incommunication and Nigeria's Development in Nwosu I. (ed.) Mass Communication and National Development. Aba: Frontier Publisher

12. Kung L Richard RO, Towse R (2008) The Internet and The Mass Media London

13. Elvestad E, Blekesaune A (2008) Newspaper Readers in Europe. A Multilevel Study of Individual and National Differences. European Journal of Communication 234: 425-448.

14. Ogbemi B (2007) Newspaper Readership in Port Harcourt. International Journal of Communication 6: 222-231. 
Citation: Umuerri AE (2018) Indigenes' Use of Development Messages in Newspapers. J Mass Communicat Journalism 8: 375. doi: 10.4172/21657912.1000375

Page 7 of 7

15. Umuerri, A.E (2014) "Readers Attitude towards Development Messages in Community Newspapers of Delta State. Journal of Communication and Media Research 6: 144-194.

16. Folarin B (2005) Theories of Mass Communication an Introductory Text. Ibadan: Bakinfol Publications.

17. Kunczik M (1988) Concepts of journalism: North and South, Böhlau. ISBN 3412028878, 9783412028879. FES Publications: 261.

18. Katz E, Blumler JG, Gurevitch M (1974) Utilization of Mass Communication by the Individual. In JG Blumler and E Katz (Eds.) The Uses of Mass Communications: Current Perspectives on Gratifications Research: 19-31.

19. Bulmer J and Katz E (1974) Uses of mass communication to communication research. J Broadcast Electron Media 40: 574-581.
20. National Population Commission Census Report (2006) Federal Republic of Nigeria, Ogbemi.

21. Gbadegesin A, Olopoenia R, Jerome A (2005) Statistics for the Social Sciences Ibadan. Ibadan University Press.

22. Farai IP (eds.) (2006) Methodology of Basic and Applied Research $2^{n}$ edition. Ibadan: The Postgraduate School University of Ibadan.

23. Olayinka AI, Taiwo VO, Oyelade RA, Omoera OS (2010) Broadcast Media in Family Planning Matters in Rural Nigeria. The Ebelle Scenario' J Commun 1: 77-85

24. Okigbo C (1990) Sources of Political Information in a Rural Nigerian Community. Africa Media Review 4: 49-61. 